\title{
Husserl and Dufrenne on the temporalization of the pictorial space
}

Javier EnRIQue Carreño Cobos

Franciscan University of Steubenville

The Austria Program

3292 Gaming (Austria)

jcarreno@franciscan.edu

Abstract: Already with Husserl phenomenology seeks to address the many faces and manifestations of time, including the appearance of time in images. The critical question, however, is how such a manifestation is at all possible. In our paper we consider Husserl's and Dufrenne's answers to this question. It will be found that their positions not only have much in common, but they complement one another, with Husserl's refinements of the issue of image consciousness revealing still more ways of experiencing time in images.

Keywords: Image, time, space, aesthetic.
Resumen: Ya con Husserl, la fenomenología busca estudiar las muchas facetas y manifestaciones del tiempo, incluyendo la apariencia del tiempo en las imágenes. La cuestión crítica, sin embargo, es cómo es posible tal manifestación. En este artículo se consideran las respuestas de Husserl y Dufrenne a esta cuestión. Se verá que sus posturas no solamente tienen mucho en común, sino que además se complementan, de modo que los refinamientos de Husserl sobre la conciencia de la imagen revelan todavía más modos de experimentar el tiempo en las imágenes.

Palabras clave: Imagen, tiempo, espacio, estética. 


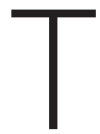

o what do we owe that in the aesthetic contemplation of certain images - such as portraits and sculptures, whether in a Classical or else (post-) Renaissance style, and in which a subject is represented-we do not find ourselves countenanced by a presence from beyond time, but by an appearance that strikes us as still temporal somehow? Bernini's David has not at all lessened the tension on his formidable sling since the last chiseling, yet seems ready to strike any minute. The wheels in Velázquez's Las Hilanderas are spinning. Obviously these images do not move, and so they are properly distinguished from images such as those that become manifest in a zoetrope or even in a flipbook, by virtue of a succession of image-phases. Yet still we cannot shake off the impression that there is temporality involved not only in our aesthetic regard of images but also in the images thusly regarded.

It is well-known that phenomenology rises up to the challenge of accounting for this awareness of temporality in depictions, most famously perhaps in Maurice Merleau-Ponty's Eye and Mind ${ }^{1}$ and in Mikel Dufrenne's Phenomenology of Aesthetic Experience. ${ }^{2}$ The same question reappears in the work of Roman Ingarden, ${ }^{3}$ and, unexpectedly perhaps, in the posthumously published works of the founder of phenomenology, Edmund Husserl. ${ }^{4}$ In what follows, I would like to address the question of the temporality of images in Husserl and Dufrenne, and highlight the surprising coherence and comple-

1. M. Merleau-Ponty, Eye and Mind, in G. A. Johnson (ed.), The Merleau-Ponty Aesthetics Reader (Northwestern, Evanston, 1993) 121-149.

2. M. Dufrenne, Phénomenologie de l'Expérience Esthétique Vol. I \& 2 (PUF, Paris, 1967); M. Dufrenne, The Phenomenology of Aesthetic Experience (Northwestern, Evanston, 1973). Henceforth I shall cite Dufrenne's French original as PE I ad PE II, and the English translation as PAE, followed by page number.

3. See for example R. Ingarden, The Ontology of the Work of Art: The Musical Work, The Picture, The Architectural Work, The Film (Ohio University, Athens [OH], 1989) 217 passim.

4. Especially in E. Husserl, Phantasie, Bildbewusstsein, Erinnerung. Zur Phänomenologie der anschaulichen Vergengenwärtigungen. Texte aus dem Nachlass (1898-1925), "Husserliana" 23 (Martinus Nijhof, The Hague, 1980); E. Husserl, Phantasy, Image Consciousness, and Memory (1898-1925) Collected Works XI (Springer, Dordrecht, 2005). Henceforth I shall cite this text as Hua 23, followed by the Geman edition and the English edition page numbers. 
mentarity between their approaches. ${ }^{5}$ Amongst others, I will show that one important reason why both thinkers can address the phenomenon of image temporality is their sensitiveness to the ways in which a subject imaginatively participates in the manifestation of an aesthetic fiction. To better gleam the latter point, I will first canvas Husserl's thoughts on image consciousness, drawing attention to parallels in Dufrenne, before turning to a more thematic comparison of their insights on image temporality.

\section{AesthetiC AND DePiCtive IMAGE CONSCIOUSNESS IN HusserL}

"All art is 'aesthetic'; it is delight in what is seen in concreto."

Husserl initiates a way of understanding the work of art that primarily connects it to aesthetic experience as an intentional consciousness. ${ }^{7}$ Intentionality names the very wonder that consciousness is consciousness "of" an object, and reveals the correlation between subjective acts of consciousness and the objectivity intended in them. Hence, rather than simply registering the presence of things, or else the mere arousal of feelings of pleasure or displeasure, in aesthetic consciousness we are intentionally directed to an objectivity, becoming particularly attentive to the very manner of its manifestation while sidelining other interests typical of the natural attitude. It is not surprising that in a now famous letter to the poet Hugo von Hofmannstahl in 1907, the father of phenomenology would compare the production and aesthetic reception of artworks to the acquisition of an intuition "enacted under a strict suspension of all

5. While Dufrenne visited the Husserl Archives in Leuven, I have not found indication in his text of having consulted the manuscripts that Eduard Marbach eventually edited and published as volume 23 of the Husserliana. My reason for comparing and contrasting Husserl and Dufrenne here is thus topical and will not suppose that Husserl's influence on Dufrenne extended beyond the Husserlian texts published prior to 1953 .

6. Hua 23, 542/654.

7. See J. Taminiaux, Intersection between four Phenomenological Approaches to the Work of Art, "Fenomenología y Hermenéutica. Actas del I Congreso Internacional de Fenomenología y Hermenéutica" 1/1 (2008) 13, 29. 
existential attitudes of the intellect and of the will" similar to the intuition of phenomena achieved within the phenomenological suspension's neutrality modification of the existential thesis of the world. ${ }^{8}$ And indeed, it would appear that the artist-like the poetic voice that marvels in Gerard Manley Hopkins' "Pied Beauty"is far less interested in the use or worldly significance of what it names_- "[...] rose-moles all in stipple upon trout that swim"—and far more in its very appearance, which the poet's eloquent verse declares beautiful. ${ }^{9}$

Aesthetic experience is thus an intuitive consciousness, a way of becoming aware of an objectivity in its present manifestness. And yet, for Husserl, works of art are distinguished from other objects present within our perceptual field of regard by their being imagistic or representational in character. In other words, works of art cannot be simply and purely perceived as things, but our approach to them, however intuitive, must be also mediate and marked by the manifestation of things in their absence from the present. Thus, what Husserl calls image consciousness is "the essential foundation for the possibility of aesthetic feeling in fine art. Without an image, there is no fine art. And the image must be clearly set apart from reality." 10 All art is 'imagistic' or 'representational' for Husserl, and if we took 'representation' here quite broadly, not only Husserl but in fact most phenomenologists would agree. ${ }^{11}$ It is also true, however, that at least initially what Husserl understands by an image falls mainly along the lines of depictions, or images in which what he calls 'pictorialization' [Verbildlichung] takes place. Let us then turn to a more focused analysis of depictive image consciousness.

8. See E. Husserl, Husserl an von Hofmannsthal, in E. Schuhmann, K. SchuHMANN (eds.), Edmund Husserl Briefwechsel Band VII (Kluwer, Dordrecht, 2004) 133-136. For an English translation (by S-O WALlENsteIN) see E. HusserL, Letter to Hofmannsthal, "SITE" 26/27(2009) 1.

9. G. M. Hopkins, Pied Beauty, in M. Ferguson ET AL. (eds.), The Norton Anthology of Poetry, $4^{\text {th }}$ ed. (Norton, New York, 1996) 1063.

10. Hua 23, 41/44.

11. See J. B. Brough, Representation, in H. R. Sepp, L. EmbreE, Handbook of Phenomenological Aesthetics (Springer, Dordrecht, 2010) 281-286. Here 281. 
First of all, it is important to place image consciousness in the context of the general division of intuitive acts into a) acts of presentification [Gegenwärtigung] which give the intended object as corporeally present before our regard, and b) acts of representification [Vergegenwärtigung] which intend their objects as absent from the present. ${ }^{12}$ Perception [Wabrnebmung] is the only intentionality to rank under presentification (=a), for it is indeed "originary consciousness," 13 while phantasy [Phantasie] and memory rank under the title of representification $(=b)$, and contrast with perception as modified forms of consciousness. In this regard image consciousness too turns out to be a form of representification, even if one that is intimately intertwined with perception. For although when we behold an image such as a photograph, it appears before our perceptual regard amongst actually and corporeally present things, what appears photographed in it does not at all appear as corporeally present. The image thus represents something else not currently present, and in this representing Husserl finds a similarity with signs and symbols, as when an image (such as a thumbnail, or a hieroglyph) functions as an externally representative [äusserlich repräsentativ] for something else (for example, a blow-up of the same photograph). However, and unlike symbolic representations in general, an image may function in an internally representative [innerlich repräsentativ] manner, since the absent object intended by that image is effectively seen in the image (in the sense of bineinseben) ${ }^{14}$.

Both in texts published during his lifetime ${ }^{15}$ and in the posthumously published literary estate Husserl will typically distinguish three objectivities involved in our dealings with images. On

12. For presentification see Hua 23, 309. N.B. I am using the translations for these terms suggested by Nicolas de Warren. See N. DE WARren, Tamino's Eyes, Pamina's Gaze: Husserl's Phenomenology of Image-Consciousness Refashioned, in C. IERNA ET AL. (eds.), Philosophy, Phenomenology, Sciences (Springer, Dordrecht, 2010) 303332.

13. See E. Husserl, Analyses Concerning Passive and Active Synthesis: Lectures on Transcendental Logic (Kluwer, Dordrecht, 2001) 40.

14. See Hua 23, $35 / 38$ and $53 / 57$.

15. For example, in E. HusserL, Ideas for a Pure Phenomenology and Phenomenological Philosophy. First Book: General Introduction to Pure Phenomenology (Hackett, Indianapolis, 2014) 216-217. 
the one hand the physical image [physische Bild]-i.e., the photographic printed-paper, the chiseled marble rock, the painted canvas, the carved wood-awakens the mental image [geistige Bild] or image object [Bildobjekt], i.e., "the person or landscape appearing in the colors of the photograph, the white form appearing through the sculpture, and so on."16 What appears, however, is the subject [das Sujet] of the image- "the landscape itself, which is not meant in these diminutive dimensions, not meant as colored in grayish-violent as the landscape in the photograph is, but in its actual colors, size, and so forth." 17

One might be tempted by Husserl's language here to consider the subject of the image to be the same as the object of perception. However, the image subject is a moment of the image. ${ }^{18}$ And although one identifies real persons in photographs, one is not committed here to say that real life persons actually appear the way depicted persons appear in photographs.

From what has been said it becomes clear that it takes more than simple perception [Wabrnebmung] to encounter an image and become aware in it of something absent. Image consciousness in fact supposes a double or dual consciousness. Firstly, image-consciousness comprises the perceptual [perzeptive] consciousness of the image object. In terms familiar from his earlier Logical Investigations, Husserl describes the awareness of an image as a distinct act of apprehension or interpretation [Auffassung] on a complex of sensations, and this apprehension differs from the case of perception since the appearing image is not some thing actually existing before our perceptual regard, but rather a perceptual nullity or "nothing" [ein Nichts]. As Husserl explains,

16. Hua 23, 29/30.

17. Ibidem.

18. As Regina-Nino Mion asks "For how can a real life object 'entwine' with an appearing image or even 'partially coincide with it'?". See her excellent discussion on the situation of the image subject vs. the corresponding thing in reality (particularly in photography-based arts) in R.-N. Mion, Husserl and Cinematographic Depictive Images: The Conflict between the Actor and the Character, "Studia Phænomenologica" 16 (2016) 269-293. Here 276. 
What actually exists there, apart from the 'painting' as a physical thing, the piece of canvas with its determinate distribution of color pigments, is a certain complex of sensations that the spectator contemplating the painting experiences in himself, as well as the apprehension and meaning [Meinung] that he bases on this complex so that the consciousness of an image occurs for him. ${ }^{19}$

Elsewhere Husserl describes the consciousness of an image object less in terms of an inner interpretation of a complex of sensations and more in terms of an externalization or projection of a phantasy which is sustained by a perceptual figment.

Something not present [ein Nichtgegenwärtiges] (something that in other circumstances would be intuitive and even be presented [vorstellig] in a reproduction or else in a perception) is pictorialized and rendered perceptible to the senses for me in the perceptual figment. The figment masks [verdeckt] from me the representified (reproductive) presentation, coincides with it; what is representified [das Vergegenwärtigende] slides into what is present [das Gegenwärtige], which in turns into what is exhibiting [Darstellenden.$^{20}$

Whether the consciousness of the image object originates in a positing perception (of, e.g., a printed paper) by gaining a new imaginative interpretation, or whether it originates in a phantasy that gains actually experienced sensuous contents, the perception of the physical image thing itself becomes 'depleted' or 'empty,' as its sensuous contents are simultaneously apprehended as an image object: "precisely as far as the design as a whole extends, we see, not paper, but plastic shapes."21

19. Hua 23, 22/23. Emphasis in the original.

20. Hua $23,383-384 / 456$. N.B., the translation slightly modified.

21. Hua 23, 45/49. 
Moreover, the consciousness of the image object itself is not left self-standing. Secondly, then, image consciousness comprises an imaginative apprehension of the image subject in the image object.

[T] he intuition of the image object awakens precisely a new consciousness, a presentation of a new object, which has an internal affinity [innere Verwandtschaft ] with, a resemblance to, the image object as a whole and, as far as particular details are concerned, with respect to certain of its points. ${ }^{22}$

The motivating bridge between these two moments of awareness (i.e., consciousness of the image object and consciousness of the subject) are the points of resemblance, or analogizing traits, through which "the subject looks at us, as it were." ${ }^{23}$ But already from Husserl's own examples (involving black-and-white photographs) as well as our comments above regarding the disparity between the image subject and something perceived, it is clear that resemblance between these objectivities only goes so far. Thus, image consciousness is marked by the awareness of conflict and of nullity not only coming from the apprehension of an image as a figment or nullity within the perceptual field of regard, but also from the realization that the image depicts its subject only to an imperfect degree. Husserl's description here would almost seem to play on the common refrain that two negatives make one positive. For even though image consciousness does not posit the existence of the subject within the framed space, the dual awareness of conflict prevents images from being discarded the way the perceptual figments of illusory perceptions are discarded as contested. In contrast to a perceptual figment, an image, by being doubly (and simultaneously) contested, is not a contender for a positing perception, and never announces itself as bringing to appearance something present. In one remarkable passage, Husserl understands this dual conflict in temporal categories, effectively signaling an "image time:"

22. Hua 23, 31/32.

23. Hua 23, 30/31-32. 
So we have appearance here, sensuous intuition and objectification, but in conflict with an experienced present. We have the appearance of a not now in the now. "In the now," insofar as the image object appears in the midst of perceptual reality and claims, as it were, to have objective reality in its midst. "In the now" also insofar as the image-apprehending is something temporally now. Yet on the other hand a "not now" insofar as the conflict makes the image object into a nullity that does indeed appear but is nothing $[\ldots] .^{24}$

We will turn to this very question of the "not now" in image momentarily. First, however, we need to address a development in Husserl's understanding of image consciousness that puts him in the vicinity of Mikel Dufrenne's understanding of aesthetic experience.

\section{NON-DEPICTIVE IMAGE CONSCIOUSNESS IN HuSSERL AND DUfRENNE}

"Earlier I believed that it belonged to the essence of fine art to present in an image, and I understood this presenting to be depicting [Abbilden]. Looked at more closely, however, this is not correct." 25

From out of an understanding of art as imagistic and depictive, Husserl goes on to signal (in a text $c a$. 1918) that no matter how imagistic, art is not for that matter generally or exclusively concerned with depictions. He begins to grapple this point particularly in connection to the theater. At a theatrical presentation, the appearance of an actor in disguise would not strike one as resembling or analogizing to a degree a person of the drama. Neither would one necessarily think of the actor as simply a trigger for certain complexes of sensations to emerge within the viewer's field of regard to be apprehended as an image. The actor is certainly pre-

24. Hua 23, 47-48/51. Emphases in the original.

25. Hua 23, 514/616. 
sent before his public, but however in plain sight, he is "concealed" both by his own bodily imagination of himself as the character as well as by the viewer perceptually imagining the character in him. What phantasy as "perceptual phantasy" [perzeptive Phantasie] or as "immediate imagination" [unmittelbare Imagination] here does is to habilitate both the actor and the viewer to take his actingalready presented by a perception—as enacting a fictive character and situation.

It will be noted that by taking into the imaginary entire, actually perceived objectivities rather than complexes of sensation, perceptual phantasy does not distinguish between three objectivities-physical image, image object, and image subject-but only two: what is actually perceived, on the one hand, and on the other hand what is taken as fictive. In other words, instead of producing an intuition in the manner of depiction of an absent subject, what image consciousness as non-depictive perceptual phantasy here does is to take what is already perceptually and intuitively available into a neutrality modification as fictive. ${ }^{26}$ However startling at first, Husserl is entirely right to declare that aesthetic phantasy operates not only on the level of producing intuitions of absent subjects on the basis of complex of sensations, but also on a non-intuitive level ${ }^{27}$ by merely bringing about a neutrality modification of the thetic or belief component of perceptions which already display fully constituted objects within the perceptual field of regard. It is by virtue of such a non-intuitive phantasy act that, as revelers and onlookers,

26. Rudolf Bernet has explained Husserlian depictive phantasy's neutrality modification as follows: "In perceptual phantasy, the modification of neutrality is applied to a perceptual consciousness, which is to say, an act of perception impressionally experienced by internal consciousness. In this way, the aesthetic perception of the irreal image-object of a painting is accompanied by a neutralization of the material existence of the traits and the colors that I actually perceive on the canvas of the painting". R. BERNET, Consciousness of the Absent and the Fictitious, in Proceedings of the Husserl Circle at University College Dublin (Humanities Institute of Ireland, Dublin, 2005) 139-152, here 143-144.

27. Cf. Hua 23, 514/616: "Art is the realm of phantasy that has been given form, of perceptual or reproductive phantasy that has been given form, of intuitive phantasy, but also, in part, of nonintuitive [unanschaulicher] phantasy. It cannot be said that art must necessarily move within the sphere of intuitiveness." 
we see things and persons on display as pure show [Schein] without believing or else disbelieving in what appears.

Naturally it goes without saying that the performance of this modification and the inauguration of a perceptual phantasy must necessarily follow certain cultural clues geared towards guiding the spectator towards performing this particular suspension. ${ }^{28}$ As Husserl explains,

'Experience' [Erfabrung] teaches [...] [that] certain things show themselves to be suited to excite a double apperception; [...] Their perceptual appearances, or those belonging to certain circumstances favorable in this respect, easily change into other perceptual modes of appearance, and do so in such a way that the stock of what is genuinely perceived is common, or almost entirely common, to both perceptions entering into the conflict-unity while the stock of what is not genuinely perceived (of what is co-perceived) on both sides is the ground for the conflict-relationship. And these things are then offered under such circumstances to perception or to the perceptual consciousness of conflict, and are supposed to cause us, in shifting to a mere phantasy, to place ourselves on the ground of the cancelled perception, hence to inaugurate a purely perceptual phantasy. ${ }^{29}$

Thus the aesthetic contemplation of artworks requires a non-intuitive use of phantasy in relation to perception, for three reasons. Firstly, it is by a particular accomplishment of perceptual phantasy's neutrality modification that I take actual things offered in perception as fictive, and this neutrality modification is prompted by cultural knowledge of, e.g., the point of theatrical representation. I see

28. Cf. Hua 23 516/618: "In the case of a theatrical presentation, the play -this section of an illusory world- appears, but we do not begin with a normal perception. We do not begin with the thesis of the reality of what appears perceptually. On the other hand, conflict exists here too, only conflict that is there from the beginning $[\ldots]$ We know that what is happening here is play acting."

29. Hua 23, 517-518/619. 
the actor on stage, and I am ready to take him as the person of the drama, not because he "looks like" this person to a limited degree, but because I already grasp his imaginative pretense. Second, it is by phantasy that I keep as distinct and incommensurable the world of perception and the world of fiction. Behind the King's room on stage there is no castle to be perceived, but by a non-intuitive phantasy (one that does not have to intuitively render the unseen sides of this fictive, staged world) I extend that world of fiction while being aware of its conflict with the actual, real world. Thirdly, I do not act upon that awareness of conflict because by participating in the show (as onlooker) I effectively displace myself into the enacted world of fiction. ${ }^{30}$

How this new understanding of art as moving within the sphere of non-intuitiveness and non-depictability impacts concretely other visual fine arts, particularly painting, is a matter that Husserl did not elaborate as thoroughly. ${ }^{31}$ Perhaps only in the following comment (either from 1916 or from 1918) Husserl returns to this issue.

All art moves between two extremes. A) Image art: presenting in an image, depicting, mediating through image consciousness. B) Art that is purely a matter of phantasy, producing phantasy formations in the modification of pure neutrality. At least producing no concrete depictive image. The 'once upon a time' is still related to the actual now and the world, and conflict with it can indicate an imagery that nevertheless does not constitute a visible image object. Music. Playful Phantasy. ${ }^{32}$

However, more than simply reading here a Husserlian gesture towards non-figurative or abstract art, or else to idealistic figurative

30. For more on Husserl's understanding of imaginative displacement [Versetzung] see R. SoKolowski, Displacement and Identity in Husserl's Phenomenology, in S. IJsSELING (ed.), Husserl-Ausgabe und Husserl-Forschung (Kluwer, Dordrecht, 1990) $173-184$.

31. For a more detailed examination of how Husserl approached concrete works of painting, see D. THIEL, Der Phänomenologe in der Galerie. Husserl und die Malerei, in Axiomathes 9/1-2 (1998) 35-47.

32. Hua 23, 540/651. 
art, ${ }^{33}$ we should consider the possibility that by virtue of perceptual phantasy's neutrality modification other perceptually available elements of the painting as a physical image thing — such as the texture of the paint brush stroke-are 'taken up' as playing a role in the image. Normally in depictive image consciousness the physical image thing is neutralized for the sake of harvesting the corresponding complexes of sensations. However, in regarding Rembrandt's The fewish Bride I am invited to take the bright texture of the brushstrokes not only as a vehicle for bringing to intuition the image of the lover's embrace of his bride; but also, as the very texture of that powerful embrace.

It is at this point that we turn to Mikel Dufrenne-notwithstanding his explicit caveat that in taking up the phenomenological method he is not following Husserlian phenomenology as much as Sartre's and Merleau-Ponty's versions of the phenomenological endeavor ${ }^{34}$ - because of how remarkably close his analyses can seem in relation to the foregoing Husserlian account of perceptual phantasy. ${ }^{35}$

In typical phenomenological fashion, Dufrenne affirms the intentional correlation and interdependence between the aesthetic object and the aesthetic experience while specifying (in ways that are coherent with Husserlian doctrine) the difference between the work of art (as approached outside aesthetic consciousness) and the aesthetic object. ${ }^{36}$ Moreover, Dufrenne emphasizes the reciprocity and complementarity between these two poles of aesthetic experience-the conscious subject and his performances, on the one hand, and the work of art which seeks to become an aesthetic object. Fur-

33. Of which he goes on to speak on Hua 23, 541-542/653-654.

34. "It will be seen that we are striving to follow Husserl to the letter. We understand phenomenology in the sense in which Sartre and Merleau-Ponty have acclimated this term in France: a description which aims at an essence, itself defined as a meaning immanent in the phenomenon and given with it" (PAE xlviii/PEA I 4-5).

35. As E. S. CASEY puts it, "Dufrenne is faithful to his origins in Edmund Husserl [...]." See his Mikel Dufrenne (1910-1995), in H. R. SEPP, L. EMbrEe (eds.), Handbook of Phenomenological Aesthetics (Springer, Dordrecht, 2010) 81-84. Here 81.

36. Ibidem. 
thermore, Dufrenne calls this aesthetic awareness a perception. ${ }^{37}$ But, as we will see in a moment, this perception, however entangled with the sensible, does not exclude a deep, imaginative involvement on the one hand, and on the other hand an awareness of "the empirical conditions of aesthetic experience" embedded in the cultural world. ${ }^{38}$

Fairly early on in his Phenomenology of Aesthetic Experience Dufrenne gives us a telling example-a visit to a performance of Wagner's Tristan and Isolde-to develop the fine points of the relation between the work of art and the aesthetic object. Underlying the aesthetic object are all the elements pertaining to the production of the opera, including the spectators- "for it is no more irrelevant [for the aesthetic perception] that thousands of gazes converge and that a human intercommunication is knit in silence." 39 He goes on to describe the appearance on stage of the actress: "Kirsten Flagstad, who has such splendid air of health, is not Isolde, the frail Isolde who is dying of love. Small matter, for what counts is her voice, which must be and is the voice of Isolde [...] [for] the opera singer is neutralized, perceived only in her role, not as herself." 40 Like Husserl, Dufrenne insists on the voluntary and informed character of the spectator's neutrality as the manner in which we distinguish the real world from the world of fiction:

I indeed relate to Tristan and Isolde through the singers, but not as a dupe. I do not call the doctor when I see Tristan stretched out on his couch, and I am fully aware that he is a legendary being who is as mythical as a centaur. Besides, marginal perceptions keep reminding me that I am at the theater as a spectator. Thus Tristan and Isolde are, as Husserl says of the Knight and Death in Dürer's engraving, "merely depicted," constituting a mere portrait. ${ }^{41}$

37. PAE lii/ PEA I 9-10.

38. PAE liii/PEA I 11.

39. PAE 7/PEA I 36.

40. PAE 7-8/PEA I 36-37.

41. PAE 9/PEA I 38. 
We now know (in light of posthumous writings) that Husserl would not necessarily agree with this understanding of performance arts as merely depictive. But both thinkers would of course agree that a phantasy modification of positing perception is at work in the spectator.

However, a more relevant matter for discussion here is Dufrenne's suggestion that phantasy's neutrality modification does not only originate in the spectator. For Dufrenne, in attending to the performance, it also feels "as if the neutralization were proceeding not from me but from the objects themselves." 42 Husserl could agree with this statement-but only as far as dramatic representation is concerned, because the actors themselves do perform a perceptual phantasy, a modification that is apparent to them as actorseven if this modification is not as apparent at first to unexperienced spectators of the drama. ${ }^{43}$ In addition, Dufrenne describes the belief neutralization situation of what Husserl termed perceptual phantasy as follows:

Nearly everything happens as if, during the play, the real and the unreal were balancing one another [...] I do not posit the real as real because there is also the unreal which the real designates [désigne]; I do not posit the unreal as unreal, because there is also the real which promotes and supports this unreal. ${ }^{44}$

Husserl would also seem to be in agreement that for the informed theater goer a sort of balance is struck between the real and the unreal without mutual cancellation. In a passage to which we have alluded earlier, Husserl has the following to say:

42. PAE 10/PEA I 39.

43. In "La Busca de Averröes" Jorge Luis Borges describes how a theatrical representation might have appeared to a traveller coming from a culture lacking a dramatic tradition and thus lacking the aforementioned empirical clues for perceptual phantasy. In his recount of the theater -which, apart from the dramatic use of imagination, truly appears to unacquainted spectators as a borderline madhouse- the traveller says "They were not mad [...] They were figuring, one merchant told me, a story." J. L. BoRGEs, La Busca de Averröes, in Obras Completas, vol. 1 (Planeta, Bogotá, 2007) 700-707. Here 704. (Translation from the author).

44. Ibidem. 
But we (who are not children) do not carry out any cancellation understood as active negation, any more than we actively carry out the consciousness of reality belonging to actual experience in which the actors and "presenting" things are given to us as actual [...] And we must also note that we do not alternate intuitively between reality and illusion [...]. Rather, without alternating, we have from the beginning only the artistic "image"; and what is real that functions as presentation, what is actually experienced without modification is continuously concealed [verdeckt] - concealed, though there is consciousness of it, only consciousness of it nonintuitively and in the peculiar fashion that the word "concealment" suggests in this case. ${ }^{45}$

One should immediately notice as a point of contrast that what Dufrenne calls a "designation" of the unreal by the real is for Husserl not quite the work of a symbolic consciousness (even if nonintuitive) but of a nonintuitive imaginative consciousness that "conceals" the real under the imaginary-even if the actor is never quite fully concealed.

To return to Dufrenne's argument, the real and the unreal do not constitute the aesthetic object properly speaking, but in the case of the opera they are themselves in service of the song, which for Dufrenne is the primary aesthetic object of the opera. While all other elements of the production are present and necessary for the work of art to emerge, the aesthetic object reduces ultimately to the sensible or perceptible element-more precisely the manner in which the sensuous or perceptible element communicates the work in a living presence.

To conclude this section, it seems that Dufrenne agrees and complements in the main Husserl's assertions regarding art as seeking to convey an intuition within a neutrality suspension. Dufrenne would also concede that art is imagistic, if by this is understood that the manifestation of the arts call for an imaginative involvement in perception. Moreover, it appears that for both Husserl and Du-

45. Hua 23, 518/618. 
frenne the aesthetic contemplation of a work is not limited simply to enacting a show, but also has to do with becoming attentive to the very sensuous (or intuitive) manner in which the show comes to manifestation.

Having seen the interrelation between aesthetic consciousness and the manifestation of the aesthetic object in an aesthetic perception involving perception and phantasy, let us now compare and contrast Husserl and Dufrenne on the temporality of images.

\section{THE TEMPORALIZATION OF PICTORIAL SPACE IN HUSSERL AND DUfRENNE}

"Rest or change appears in the image. In the ordinary resting image, which depicts by means of an unchanging image object, a movement might appear-a rider galloping away in a painting $[\ldots]]^{\prime 46}$

To what do we owe that a static image might exhibit for us not just a subject at a moment of time but also a movement? Answering this question meaningfully requires that we distance ourselves from the standard thesis (dating as far back as Lessing's Laocöon) ${ }^{47}$ that a static image—such as a painting or a sculpture-can only exhibit one moment of time, and therefore, for aesthetic purposes, it ought to exhibit the most telling moment of an event to signify it. And it would seem that Husserl has good reasons to distance himself from this position, given his originary contention of a perception as an awareness of an "extended present" as opposed to the awareness of an isolated and abstract "now-point."

Even though Husserl does not come to mind as a phenomenologist delving deeply into the aesthetics of static image temporality, it is important to note that for a time he earnestly asked how an image could convey a time- - the reason being that he thought (at

46. Hua 23, 489/584.

47. See G. Lessing, Laocöon, in H. AdAms (ed.), Critical Theory since Plato (Harcourt, New York, 1971) 349. 
least initially) that there was something imagistic to our awareness of the past.

The painting furnishes a perceptual presentation, but what is now is the representant of something that is not now. Of course, not every painting represents a time [eine Zeit], but think of paintings of historical events: the execution of Charles II, the storming of the Bastille, and the like. Yet these are not memories. $^{48}$

In this reference, the "not now" in image is understood as a temporal now, just like in the passage about the "image now" with which we closed our first section supra. However, both Husserl's understanding of time-consciousness and of image time undergoes important development. Let us address each briefly in turn.

Firstly, in the course lectures that were eventually edited as $O n$ the Phenomenology of the Consciousness of Internal Time, Husserl connects time and time-awareness. The time which comes under the purview of a description of consciousness is not, however, real or transcendent time, but the time of appearing, the immanent time which "cannot be measured; there is no clock and no other chronometer for it. Here one can only say: now, before, and further before, changing or not changing in the duration, etc." 49 Moreover, Husserl realizes that time-consciousness, rather than piecing an awareness of elapsed phases and now-phases of consciousness, is always already of an intentional threefold character. We are aware of an object as present because we experience it (a) in one of its phases as 'now,' (b) in one or more of its phases as 'just-having-been now,' and (c) still in other forthcoming phases as 'not-yet-now.' So consciousness always already manifests a temporal structuring: we are internally and originally aware of the 'now phase' in "primordial impression

48. E. Husserl, On the Phenomenology of the Consciousness of Internal Time (18931917) (Kluwer, Dordrecht, 1991); E. HusserL, Zur Phänomenlogie des inneren Zeitbewusstseins (1893-1917)(Martinus Nijhoff, The Hague, 1966). Henceforth Hua 10 followed by the German and English page numbers. Here 184/190.

49. Hua 10, 339/351. 
or primordial sensation;" of the elapsed phases, in "retentions," and of the forthcoming phases in "protentions."Accordingly, Husserl insists that the term "now" is not a name for a part of a temporal object, or even for an objective phase, but rather, the term "now" names the mode of appearance of an objective phase. Furthermore, the "now" is a relative concept, as it refers to a "past." ${ }^{50}$ For the "now" is the source of new time-points in a temporal continuum running off. ${ }^{51}$

Secondly, this necessity to consider a temporal extendedness already on the basis of the representation of a now phase would cohere with Husserl's suggestion that there can be an "adequate depiction" of an event and not just of a thing, such as a painted leap or a painted run. ${ }^{52}$ John Brough has ably incorporated this Husserlian endeavor to account for this Husserlian insight as follows:

We do not consider it at all odd if an art critic writes that a painter has captured a 'fleeting instant.' We do not consider it odd because we see a fleeting instant in the image-object that appears to us when we look at the painting. We may not see a succession of moments or events, but we do see a single moment. And it appears as a moment only insofar as it appears to us as part of a temporal context, a temporal succession. If one says that it appears to us as a depicted now-moment, then, in common with every now, it appears with a halo of past and future. It cannot be snatched cleanly from its context with all of its temporal references scrubbed away. ${ }^{53}$

50. Hua $10,68 / 70$.

51. For two more extended (and lucid!) introductory presentations of Husserl's doctrine of time-consciousness, please see J. BROUGH, The Emergence of an Absolute Consciousness in Husserl's Early Writings on Time-Consciousness, "Man and World" 5/3 (1972) 298-326 and J. BROUgH, Husserl's Phenomenology of Time Consciousness, in J. Mohanty, W. R. MCKenna (eds.), Husserl's Phenomenology: A Textbook (University Press of America, Washington, 1989) 249-289

52. Hua 23, 493/587-588.

53. J. Brough, Plastic Time: Time and the Visual Arts, in J. Brough, L. EmbreE (eds.), The Many Faces of Time (Kluwer, Dordrecht, 2000) 223-244. Here 236. 
Husserl, however, is brought to hesitation (saying "This is something to ponder" ${ }^{54}$ ) when he refers the phenomenon back to the threefold distinction between image thing, image object, and image subject. "Is this the perception of a leap serving as an image for a leap?" ${ }^{55}$ Hardly, because

the modes of givenness, the modes of appearance [of both the image object and the image subject] are firmly shut off, no matter how they may run over into continuations by means of phantasy: as when I allow myself to be drawn into the phantasying of the running [...] The runner belongs to another time and to another space [...] but the phase of time to which he belongs is 'presented' as detached and does not abide in time, and is not a really enduring phase. ${ }^{56}$

Is it possible that these continuations into, e.g., memory or phantasy, however external to the static image, are not inessential for a rapprochement between images and time? For the subject appearing in image may 'bring to mind' recollections or phantasies that are entirely appropriate to is "as when, on seeing the pictures of Paolo Veronese, we feel transplanted into the magnificent, opulent life and activitiy of the grand Venetians of the sixteen century." ${ }^{57}$ Is not this the way in which we suspect time on the side of images? For how else could something purely non-temporal, a purely non-temporal phase, engage us to imagine something temporal even in it?

It is at this point that I would like to pass this question to $\mathrm{Du}-$ frenne, whose rich treatment of the temporalization of pictorial space is influenced not so much by Husserlian time-consciousness as by the Kantian thesis of temporality and spatiality as pure forms of sensible intuition (and of time as the form of inner sense) ${ }^{58}$ Clearly the reason behind Dufrenne's strategy is to affirm a certain solidar-

54. Hua 23, 493/588.

55. Ibidem.

56. Hua 23, 537/646.

57. Hua 23, 37/40.

58. Cf. M. Dufrenne, PAE 242ff./PEA I $306 f f$. 
ity between space and time, such that, e.g., music - the temporal art par excellence is found to be spatial, and painting, the purely spatial art, cannot be thought out sufficiently without reference to time.

In order to make this thesis clearer, Dufrenne challenges the primacy of representation in painting. For "even though it is primarily figurative, [painting] involves a treatment of the sensuous which is not solely ordered by a concern for representation." 59 Within his analysis, Dufrenne distinguishes between the pictorial object and the represented object-roughly analogous to the previously seen Husserlian distinction between the image object and the image subject-and claims that when the represented object holds the viewer's entire attention at the expense of the awareness of the pictorial object "then the temporal dimension of painting cannot appear." ${ }^{\circ}$ Here it is important to observe that Husserl would only partly agree with Dufrenne's statement. Even after considering the point that both the static image and the image subject are "ideal objectivities" not changing in a temporal duration, Husserl would still say that the manifestation of an image space comes hand in hand with an awareness of an image time. However, Husserl, as much as Dufrenne, would also admit that the development of this image temporality would require a playful imaginative engagement that is ready to entertain more than what the image simply and patently offers in its depictive function.

Accordingly, Dufrenne sidelines a) the level of temporality pertaining to the represented (image) subject, famously stating that "Van Gogh's olive trees, desperately twisted in the soil by their convulsive roots, are more actively in motion than Gericault's horses." ${ }^{1} 1$ Likewise, b) the 'objetive time' belonging to the physical image thing, while not irrelevant, nevertheless does not cut to the heart of the experiential temporality of images. More important still is the c) time involved in seeing the painting: for "it is by this movement that the movement of the object appears." ${ }^{2}$

59. PAE 241/PEA I 305.

60. PAE 274/PEA I 345.

61. PAE 279/PEA I 351.

62. PAE 278/PEA I 349. 
And yet, Dufrenne admits, "this quasi-imperceptible and unregulated movement hardly awakens in us the feeling of duration [...] The pictorial object becomes animated only by affecting us more deeply than this." ${ }^{63}$

The remaining source of temporality in the image, therefore, is this $\mathrm{d}$ ) internal duration belonging to the picture. There are, however, further specifications of the sources and characteristics of this duration. On the one hand $\mathrm{d} 1$ ), in its lines and colors "the plastic element vibrates as if it retained something of the movement of the hand which placed it on the canvas" ${ }^{4}$ and which the pictorial object in turn quickens in the spectator. And on the other hand, d2) because the aesthetic object is meaningful and seeks to signify, one can speak here-however metaphorically_of a "movement toward meaning." 65

While this last view of temporality $(=\mathrm{d} 2)$ rests on a particular understanding of metaphors, one will find it fairly analogous to the situation described by Husserl of images prompting imaginative continuations and bringing something to mind. And what an image's movement toward meaning brings to mind is a subject-though in a different sense from the depicted image subject. As Brough puts it "the signifying character simply indicates that something is represented in the work, that it has a subject, even if the subject is not some definite and identifiable person or thing." ${ }^{\prime \prime}$ This subject or meaning, according to Dufrenne, is inexpressible because it rests both in the form and in the content of the concrete painting.

Indeed, it is remarkable accomplishment for Dufrenne to place the duration internal to the image at two different book ends-on the one hand, as the conclusion to the movement in which the painting has been engendered, and which it can communicate, and on the other hand, as the vehicle for a movement towards a mean-

\section{Ibidem.}

64. PAE 278/279/PEA I 350.

65. PAE 381/ PEA I 353.

66. Cf. J. B. Brough, Representation, in H. R. SEPP, L. Embree (eds.), Handbook of Phenomenological Aesthetics (Springer, Dordrecht, 2010) 285. 
ing of unapparent (yet still personal) importance which the image prompts in the viewer.

In going through the different levels of temporality outlined by Dufrenne, one can also see that Husserl would be largely in agreement with Dufrenne. For Husserl has also thought of the temporality of the image subject $(=a)$; the objective time of the image in the sense of the real time of the physical image thing $(=\mathrm{b})$; the seeing of the painting as a temporally extended process itself $(=c)$; the attentiveness to the way in which the rendering of the image object itself gives rise to delight (=d1); and lastly the peculiarity that images prompt us to wonder and bring to mind other experiences ${ }^{67}(=\mathrm{d} 2)$.

Husserl in turn contributes to this discussion most profoundly by taking us back to his earlier claim that art-including too the pictorial arts-does not move exclusively within the confinements of producing intuitions. Just like in the theater the viewer takes some of the available materials to perceptually phantasize the drama, so also the aesthetically informed viewer takes the sensuous elements of the painted canvas as the very texture of the pictorial image world. The movement by which the imagination takes anew the sensuous contents and sees them play different roles-at one time depicting a woman (in Da Vinci's "Head of a Woman," c. 1508), at another time prompting me to think of her thoughts, at yet another time making me wonder what she is looking at, and still at another time seeking to find the starting and end points of her wondrously loosened hair-all reveal a life in this static image-paradoxically 'moving' under the viewer's gaze while staying self-same.

67. For further reference on this point see P. CrowTHER, Phenomenologies of Art and Vision: A Post-Analytic Turn (Bloomsbury, London, 2013) 138. 
